\title{
Validation of the Forage Brassica Calculator: A fertiliser forecasting system for forage brassica crops grown in New Zealand. Pasja and bulb turnips
}

\author{
E. CHAKWIZIRA, A.L. FLETCHER and R.F. ZYSKOWSKI \\ Plant \& Food Research, Private Bag 4704, Christchurch \\ Emmanuel.Chakwizira@plantandfood.co.nz
}

\begin{abstract}
Forage brassica calculators can be used to assist fertiliser consultants and farmers plan nitrogen $(\mathrm{N})$ and phosphorus (P) applications for site-specific brassica production. The cost of each nutrient and the predicted productivity are used to recommend both economic and environmentally sound application rates. In this study, simulated yield was that modelled by PARJIB (a model that analyses and forecasts yield responses to nutrients) from the soil available nutrient levels, the potential yield and the fertiliser rates. The actual (observed) yields are those measured from the field. Simulations for 'Pasja' $\left(\mathrm{R}^{2}=0.96\right.$; root mean square of the deviation (RMSD) $\leq 3 \%(0.25 \mathrm{t} / \mathrm{ha}))$ followed observed data closely with individual harvests at 60 and 90 days after sowing, consistent with observed data $\left(\mathrm{R}^{2}>0.93\right.$; $\left.\mathrm{RMSD} \leq 4 \%(0.20 \mathrm{t} / \mathrm{ha})\right)$. The 'Pasja' model is sufficiently robust to predict site specific $\mathrm{N}$ and $\mathrm{P}$ fertiliser requirements. However, the model may need to be extended to more than two grazing events. Simulations for bulb turnips $\left(\mathrm{R}^{2}=0.10 ; \mathrm{RMSD} \leq 28.1 \%\right.$ $(2.70 \mathrm{t} / \mathrm{ha}))$ was poor. Simulations predicted the same yield for different treatments within sites, while observed yields differed widely (4-12 t/ha). This was because experiments included establishment and seeding method treatments which are not currently accounted for by the calculators. Thus, practical use of the brassica calculators for assisting with fertiliser rates currently depends on other agronomic factors being managed optimally.
\end{abstract}

Key words: agro-ecological, leachate, supplementary feed, water-holding capacity

\section{Introduction}

Forage brassica crops are widely grown for supplementary feed in New Zealand, for the summerdry east coast and central North Island regions or for the wet and cold South Island winters. Forage brassica crops have been fully described by Charlton \& Stewart (2006). 'Pasja', a leaf turnip (Brassica rapa; syn. B. campestris) is for summer and autumn feeding, while 'Barkant', a bulb turnip (Brassica rapa spp. rapa or rapifera; syn. B. campestris), is for both summer and winter feeding. Research has shown that turnip crops have large total nutrient requirements (Pearson \& Thomson 1996). High nutrient uptake may lead to adverse effects on animal health and create a potential environmental risk from $\mathrm{N}$ leaching and/or $\mathrm{P}$ run-off into ground and surface water.

Forage brassica calculators were developed by The New Zealand Institute for Plant \& Food Research Limited supported by Ballance Agri-Nutrients, to optimise fertiliser decisions. They are primarily used as on-farm decision support tools to help fertiliser consultants and farmers determine strategic rates of fertiliser inputs at the start of the season. Currently, the calculators are used for determining nitrogen $(\mathrm{N})$, phosphorus $(\mathrm{P})$ and potassium $(\mathrm{K})$ application rates. However, research on the influence of $\mathrm{K}$ on brassica dry matter (DM) production has shown little or no response (Wilson et al. 2006), primarily because sedimentary soils in New Zealand are high in potassium. However, peaty soils that have no $\mathrm{K}$ in parent material and volcanic soils may show significant $\mathrm{K}$ responses so there is a need to further investigate $\mathrm{K}$ responses in these specific situations, particularly in the central North Island.

At a mean of $2.5 \% \mathrm{~N}$ in total dry matter (DM) (Cornforth et al. 1978), turnip crops producing 6-8 t $\mathrm{DM} / \mathrm{ha}$ would contain between 150 and $200 \mathrm{~kg} \mathrm{~N} / \mathrm{ha}$. Similarly, at $0.3 \% \mathrm{P}$ of total DM, the same crops will contain from 18 to $24 \mathrm{~kg} \mathrm{P} / \mathrm{ha}$. Most soils are unable to supply these amounts of $\mathrm{N}$ and $\mathrm{P}$ during the growing season and therefore fertilisers must be added. The main objective for the development of the forage brassica calculators was to calculate the nutrient requirement in high producing crops.

The actual amount of fertiliser applied is based on predetermined information such as site history and crop details, current fertiliser costs and levels of soil macro-nutrients (Figure 1) based on pre-planting soil tests. Soil sampling depth is set to a default value of the standard $150 \mathrm{~mm}$, and adjustments made for any deviations. Crop management dates and site details are linked to a PARJIB model (a simple but powerful model that analyses and forecasts yield responses to nutrients in annual crops; Reid 2002). Yield response to nutrient supply is dictated by the potential yield (PY; 
maximum yield which could be obtained by the crop at a given site driven by average climatic conditions and crop species' characteristics). The long term weather data is used to evaluate the PY for any combination of region, location, sowing date and expected grazing dates. The estimate of the crop's economic value is used to forecast the optimum amount of fertiliser needed to supplement nutrients from the soil to maximise the economic returns. Nutrient losses from fertiliser overuse are therefore minimised with the desirable benefits of reducing the cost to growers and reducing potential environmental impacts.

Some regional councils in New Zealand are proposing guidelines with strict nutrient management practices (Cichota et al. 2010), with limits on $\mathrm{N}$ concentration in the leachate under farming systems. Forage brassica calculators among other decision support tools such as the potato calculator (Jamieson et al. 2006) and the maize calculator (Reid et al. 1999) can be used to demonstrate compliance to such guidelines. In this paper we examine the performance of brassica models in four independent field trials that covered a wide range of agro-ecological zones of New Zealand.

\section{Materials and Methods}

Four experiments, with some covering three seasons, were used in the validation of the 'Pasja' and bulb turnip calculators. These include three data sets from Lincoln, described in recent papers on 'Pasja' (Chakwizira et al. 2009; Martin et al. 2006) and bulb turnips (Fletcher \& Chakwizira 2011). These will be referred to as Experiments A (Martin et al. 2006), B (Chakwizira et al. 2009) and C (Fletcher \& Chakwizira 2011). Experiments A-C were situated at Lincoln, on a deep, well-drained Templeton silt loam (Jamieson et al. 1995). A fourth experiment conducted between 2006 and 2009 (de Ruiter et al. 2009) included 'Barkant' turnip crops at two sites in Waikato. These data sets will be referred to as Experiment D. Soil details for Experiment D are in Table 1. All soil test results have been converted from MAF units to $\mathrm{mg} / \mathrm{kg}$ soil as described by Chapman \& Banister (1994).

Experiment A (Martin et al. 2006) was a randomised complete block design, replicated three times. 'Pasja' was sown on 3 December 2003 in a rain-out shelter at Lincoln, at a sowing rate of $6 \mathrm{~kg} / \mathrm{ha}$. The crop was irrigated to field capacity during the establishment phase but was exposed to eight irrigation treatments from 30 December 2003 until late March 2004 covering a range of wet to dry scenarios. Average soil test results to $150 \mathrm{~mm}$ depth of soil were: $\mathrm{pH} 6.0$; Olsen $\mathrm{P} 13, \mathrm{~K}$ 160, Ca 875, Mg 75, sulphate-S 5, Na $65 \mathrm{mg} / \mathrm{kg}$ soil and available $\mathrm{N}$ of $83 \mathrm{~kg} / \mathrm{ha}$. Diammonium phosphate (DAP; 18:20:0:2) fertiliser was applied at $125 \mathrm{~kg} / \mathrm{ha}$ at sowing. Only results from fully irrigated treatments will be used in this paper as the model has not been calibrated to account for moisture stress situations. Also, only data for 60 and 90 days after sowing (DAS) will be used as the model is calibrated to account for a maximum of two grazing events.

Experiment B (Chakwizira et al. 2009) was a randomised complete block design, replicated three times. Triple superphosphate $(0: 21: 0: 0)$ at $0,20,40$ and $60 \mathrm{~kg} \mathrm{P} /$ ha was applied either broadcast by hand and soil incorporated before sowing or banded below the seed at sowing with an Oyjord drill. 'Pasja' seed treated with "Superstrike ${ }^{\circledR}$ " was sown at $4 \mathrm{~kg} / \mathrm{ha}$ on 17 December 2007. A soil test to $150 \mathrm{~mm}$ depth was taken from each of the 24 plots individually. The average soil test results were: $\mathrm{pH} 6.2$ (5.8-6.5); Olsen P 13.3 (9-17), K 140 (80-220), Ca 1000 (875-1500), Mg 60 (40-90) mg/kg soil and available N 76 (63-107) kg/ha. Numbers in parentheses are the nutrient ranges across the individual plots.

Experiment C (Fletcher \& Chakwizira 2011) was a split plot randomised complete block design, replicated four times. It consisted of four forage brassica species as the main plots and three factorial combinations of different fertiliser $\mathrm{N}$ rates and times of application as sub-plots. For 'Barkant' turnips, Treatment 1 was 200 $\mathrm{kg} \mathrm{N} /$ ha applied on 4 December 2009; Treatment 2 was $200 \mathrm{~kg} \mathrm{~N} /$ ha applied on 4 December 2009 and a further $200 \mathrm{~kg} \mathrm{~N} /$ ha applied on 28 December 2009 (400 kg N/ ha total); and Treatment 3 was $200 \mathrm{~kg} \mathrm{~N} / \mathrm{ha}$ applied on 28 December 2009. All $\mathrm{N}$ was applied in the form of urea (46:0:0:0). Average soil test results to $150 \mathrm{~mm}$ depth of soil were: pH 6.1; Olsen P 13, K 160, Ca 1125, $\mathrm{Mg} 45, \mathrm{~S} 4 \mathrm{mg} / \mathrm{kg}$ soil and available $\mathrm{N}$ of $74 \mathrm{~kg} / \mathrm{ha}$. The experiments were sown on 18 November 2009 and the final harvest for turnips was 15 February 2010.

Experiment D (de Ruiter et al. 2009; Table 1) was also a split plot randomised complete design, replicated three times. It consisted of three methods of sowing as the main plots and three factorial combinations of two methods of DAP application and two rates of DAP ( 0 and $200 \mathrm{~kg} / \mathrm{ha}$ ) (no fertiliser, banded DAP and broadcast DAP) as sub-plots. Both sites were on volcanic ash soil (Parffit \& Clayden 1991).

The experiment at Pirongia was sown on 2 November 2007 and harvested on 16 January 2008 and the one at Henderson was sown on 3 November 2008 and harvested on 14 January 2009.

\section{Measurements}

The final DM yields for all experiments were determined by harvesting $3 \mathrm{~m}^{2}$ quadrats per plot. The number of plants was counted and fresh weight was determined. A representative five plant sub-sample was 
Soil test results for the Henderson and Pirongia sites in Waikato and optimum nutrient levels (McLaren \& Cameron 1996). Results are in $\mathrm{mg} / \mathrm{kg}$ soil unless stated otherwise.

\begin{tabular}{lllllll}
\hline Site and Year & $\mathrm{pH}$ & Olsen Pa,b & $\mathrm{K}$ & $\mathrm{Mg}$ & Sulphate-S & AMN (kg/ha) \\
\hline Pirongia (2007-08) & 5.6 & 14 & 220 & 75 & 26 & 96 \\
Henderson (2008-09) & 6.4 & 27 & 280 & 160 & 4 & 130 \\
Optimum & $5.8-6.2$ & $20-25$ & $100-140$ & $20-50$ & $10-12$ & 300 \\
\hline
\end{tabular}

${ }^{\text {aP }}=$ phosphorus, $\mathrm{K}=$ potassium, $\mathrm{Mg}=$ magnesium, $\mathrm{S}=$ sulphur, $\mathrm{AMN}$ = available mineralisable nitrogen.

${ }^{\mathrm{b}}$ Average values from all plots for both sites.

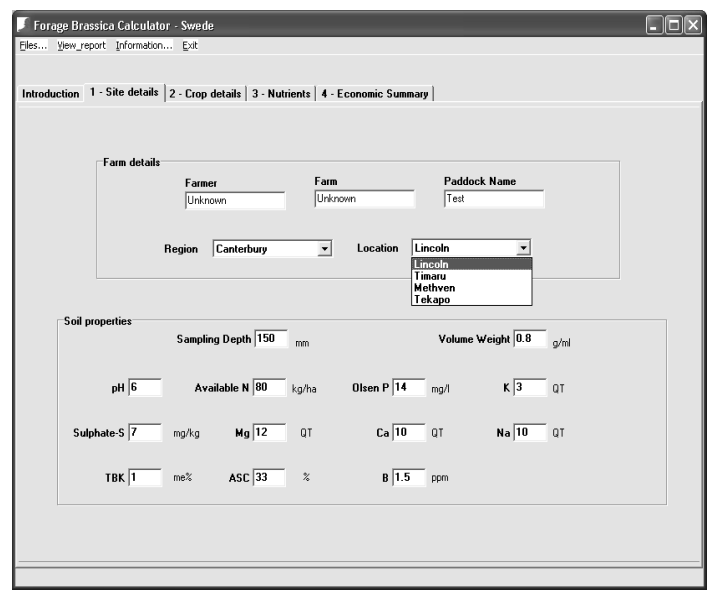

Figure 1 Interface for management set up of the forage brassica calculator.

then retained for leaf and bulb partitioning. Partitioned sub-samples were dried in a forced air oven at $70^{\circ} \mathrm{C}$ to constant weight.

\section{Meteorological conditions}

Experiments A-C were irrigated and therefore moisture was not a limiting factor except where it was a treatment. The total rainfall for Experiment D was $191 \mathrm{~mm}$ and $202 \mathrm{~mm}$ at Pirongia and Henderson, respectively, compared with the long term average (LTA) of $220 \mathrm{~mm}$. Mean temperatures for Experiment D were $3^{\circ} \mathrm{C}$ warmer than the LTA.

\section{Data analysis}

DM values were analysed by analysis of variance (ANOVA). An indication of the variation associated with means was given by the Least Significant Difference (LSD) at the 5\% level. The forage brassica calculators were run retrospectively for each of the treatments. This was based on LTA weather and actual $\mathrm{N}$ and $\mathrm{P}$ data for each treatment. The simulated yields, modelled by PARJIB model (Reid 2002) were then compared with actual yields measured from the final harvest for each crop, site and year. A 1:1 line was used to determine the fit of the actual to simulated yield for the overall data for each crop. The validation applied here for the individual sites used regression analyses of the form $\mathrm{Y}=\mathrm{a}+\mathrm{bX}$ fitted by SigmaPlot between individual sets of actual (Y) and simulated (X) data. The root mean square of the deviation (RMSD) and adjusted coefficient of determination $\left(\mathrm{R}^{2}\right)$ (Willmott 1982) were used as measures of accuracy of the simulation. The most appropriate format for the RMSD was in t/ha (Reid et al. 2002), although we also calculated the errors as percentages. An RMSD of $\leq 10 \%$ was considered as an accurate simulation for this paper. Kobayashi \& Salam (2000) have shown that the lower the value of RMSD, the closer the simulation result is to the measurement.

\section{Results}

\section{Pasja crops}

Final dry matter yield for all experiments was reliably predicted $\left(\mathrm{R}^{2}=0.96 ; \mathrm{RMSD} \leq 3 \%(0.25 \mathrm{t} / \mathrm{ha})\right)$, although there were some treatment and time to harvest inconsistencies (Figure 2). Table 2 shows that the 'Pasja' calculator estimated yield accurately for both sites and years $\left(\mathrm{R}^{2}>0.93\right.$; $\left.\mathrm{RMSD}<4 \%(\leq 0.20 \mathrm{t} / \mathrm{ha})\right)$.

The calculators do not account for water, so predicted the same yield for all the water treatments at Lincoln (Figure 2) of about 4.5 and 7.3 t/ha for the 60 and 90 days to harvest, respectively. The actual yield ranged between 4.6 and $7.8 \mathrm{t} / \mathrm{ha}$ with no differences among the actual yields.

\section{Turnip crops}

There was an interaction $(\mathrm{P}=0.003)$ between sowing method and DAP fertiliser application at Pirongia in 2008. Specifically, DM yield was lowest at $4.2 \mathrm{t} / \mathrm{ha}$ (Figure 3) when seeds were direct drilled (DD) with no fertiliser, but increased to c. $9 \mathrm{t} / \mathrm{ha}$ when fertiliser was applied and across the other treatments. Overall, the actual DM yield at Pirongia increased $(\mathrm{P}=0.005)$ with fertiliser application, from $7.4 \mathrm{t} / \mathrm{ha}$ for the control to about $10 \mathrm{t} / \mathrm{h}$ a when DAP was applied, irrespective of method of fertiliser application. However, fertiliser application had no effect on DM yield (9-10.6 t/ha) at both Henderson and Lincoln sites. Actual yields also showed that cultivation was superior to direct drilling (11.6 vs. $10.5 \mathrm{t} / \mathrm{ha}$ ) and drilling seed was superior to broadcast (9.8 vs. $8.9 \mathrm{t} / \mathrm{ha}$ ). 


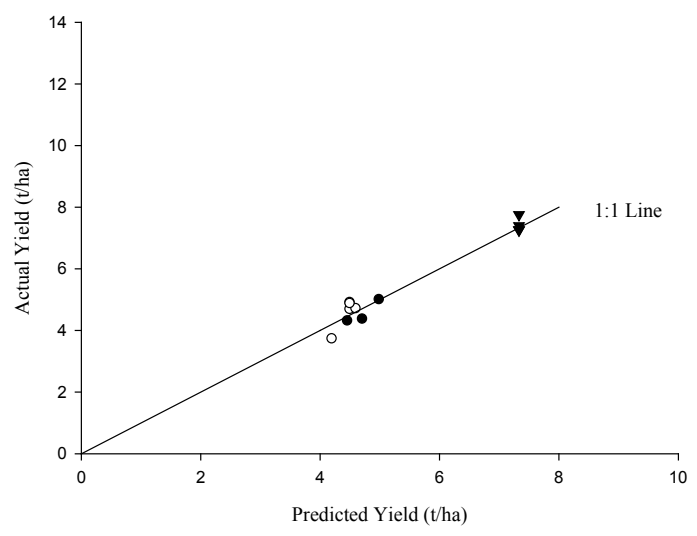

Figure 2 Actual versus predicted yields for 'Pasja' crops grown under different water regimes and harvested at different days after sowing (DAS) in 2003-04 (Experiment A): $\circ 60$ DAS, $\boldsymbol{\nabla} 90$ DAS and $(\bullet) P$ supply at Lincoln in 2007-08 (Experiment B). 1:1 line perfect agreement.

The overall DM yield simulation for turnips was poor $\left(\mathrm{R}^{2}=0.10\right.$; $\mathrm{RMSD}=2.70 \mathrm{t} / \mathrm{ha}(28.1 \%)$ ) (Figure $3)$. The calculator predicted the same yield for all the treatments at Lincoln and also similar yields for all the fertiliser treatments at the other sites. However, the actual yield varied between 9.3 and $10.4 \mathrm{t} / \mathrm{ha}$ at Lincoln and 4.2 and $12 \mathrm{t} / \mathrm{ha}$ for the other sites. The calculator under-estimated the yield at all sites (Figure 3), except for the DD control at Pirongia and the control at Lincoln. Yield prediction per site was reasonably good $\left(\mathrm{R}^{2}>0.93 ; \mathrm{RMSD}<0.8 \mathrm{t} / \mathrm{ha}(<9 \%)\right)($ Table 3$)$ at Lincoln, Henderson cultivated and Henderson cultivated and broadcast seed treatments. Simulation was less accurate $\left(\mathrm{R}^{2}>0.41-0.95 ; \mathrm{RMSD}<1.06-1.72 \mathrm{t} / \mathrm{ha}(13-16 \%)\right)$ for the remaining sites and treatments.

\section{Discussion}

Dry matter yields for the species described in this paper were consistent with those reported in the literature (Chakwizira et al. 2011). They also reflect the diversity of agronomic management and site potentials expected from these species.

The forage brassica calculators were evaluated for their ability to predict the final DM yield across years, sites and treatments. Success of the simulation relative to the observed data varied. Overall simulations for 'Pasja' ( $\left.\mathrm{R}^{2}=0.96\right)$ followed observed data closely, for both the adequately watered crops harvested at 60 and 90 DAS in 2004 and the P supplied crops in 2008. This shows the 'Pasja' calculator was able to accurately predict $\mathrm{N}$ and $\mathrm{P}$ fertiliser requirements. The two data sets used here were from Lincoln and therefore data from other agro-ecological regions is required to determine consistency of prediction.

The simulation for turnips $\left(\mathrm{R}^{2}=0.10\right)$ was poor, with
Table 2

The root mean square of the deviation (RMSD) and adjusted coefficient of determination $\left(R^{2}\right)$ for 'Pasja' crops grown at different sites (Experiment A; Figure 2).

\begin{tabular}{lll}
\hline Site & RMSD (t/ha) & $\mathrm{R}^{2}$ \\
\hline Lincoln 2007-08 & $0.15(3.2)^{\mathrm{a}}$ & 0.93 \\
Lincoln 2003-04 & $0.20(3.3)$ & 0.98 \\
\hline aNumbers in parenthesis are the percentage of RMSD.
\end{tabular}

a Numbers in parenthesis are the percentage of RMSD.

an RMSD of $>10 \%$ on $50 \%$ of the sites (Table 3 ). The poor simulation of turnip yield data can be attributed to the failure of the calculators to respond to improved agronomic management such as methods of cultivation and fertiliser application. There was a large variation in the actual yields of $4-12 \mathrm{t} / \mathrm{ha}$ (Figure 3 ) induced by method of sowing and fertiliser application. The calculators require further development to include methods of sowing and $\mathrm{P}$ application as input variables. The low yield for the DD control treatment at Pirongia was attributed to the lower $(\mathrm{P}=0.002)$ plant density, 37 plants per $\mathrm{m}^{2}$ compared with the 52 plants per $\mathrm{m}^{2}$ for the fully cultivated and fertilised crops. Methods of cultivation and sowing have been shown to influence plant density (Jacobs et al. 2001) and therefore DM production. Adams et al. (2005) have reported that maximum turnip DM yield was produced from a plant population of $\geq 45$ plants per $\mathrm{m}^{2}$. The under prediction of the turnip yield across the sites and years may be an indication that the model calibration may be wrong in its parameters for crop growth. The turnip model was based on the kale model and then adjusted for bulb and shoot partitioning and canopy development (phyllochron, leaf appearance rates and leaf sizes). These results suggest the model may need to be recalibrated and undergo further development before it can be used with confidence.

Forage brassica calculators are intended for sitespecific brassica production. The simulation within each site was excellent for 'Pasja' $\left(\mathrm{R}^{2} \geq 0.93\right.$; $R M S D \leq 0.20 \mathrm{t} /$ ha $(<3.5 \%))$ but variable for turnips $\left(\mathrm{R}^{2}=0.40-0.99\right.$; RMSD $<0.20-1.72 \mathrm{t} / \mathrm{ha}(2.3-16 \%))$. These results show that the current form of the calculators was sufficiently robust to predict potential yields for 'Pasja' crops but not for bulb turnips. Both models could be upgraded to include other agronomic factors such as the methods of cultivation, sowing and $\mathrm{P}$ application and the response to moisture sensitivity. Currently the calculators do not account for these.

The current version of the calculators is for strategic fertiliser application and they cannot be used for tactical decision-making around fertiliser $\mathrm{N}$ application. However, the general recommendations for $\mathrm{N}$ application has been to split apply $\mathrm{N}$ (Williams et al. 


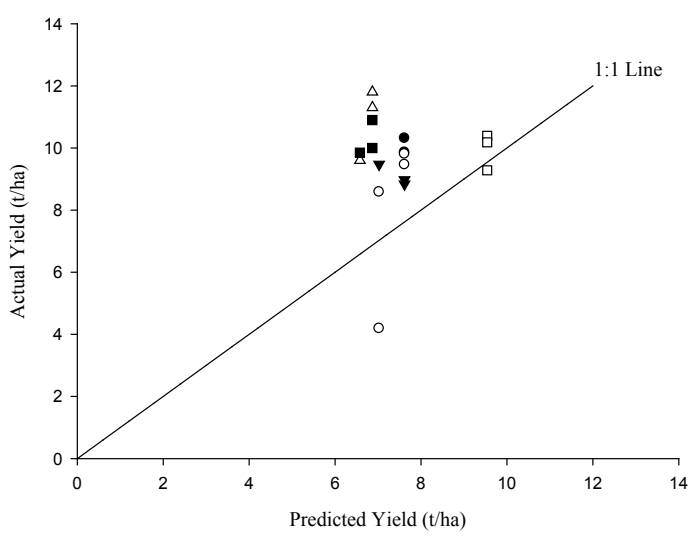

Figure 3 Actual versus predicted yields for turnip crops grown in at Lincoln ( $\square$; Experiment C) in 2010 and Waikato (Experiment D); Pirongia (2008): $\triangle \mathrm{CC}$ and - DD and Henderson (2009): - DD, ○ CC (D) and $\boldsymbol{\nabla}$ CC (B). (DD - no cultivation, seed drilled, CC (D) - cultivated, seed drilled and CC (B) - cultivated, seed broadcast). 1:1 line perfect agreement.

2003), with only a small amount (c. 10\%) applied near sowing and the majority applied to match crop demand based on key sources of risk in production such as site conditions and weather. There is scope to improve the calculators to include split application of fertilisers, as it is more economically and environmentally sound. To achieve the yield predicted by the brassica calculators, farmers should use optimum agronomic management strategies. The model predictions achieved in the calculators were based on optimum economic and environmental management for variables other than those set for fertility in the calculator runs.

\section{Conclusions}

The 'Pasja' model is sufficiently robust to predict site specific $\mathrm{N}$ and $\mathrm{P}$ fertiliser requirements. However, the results from the turnip model suggest it may need to be recalibrated and undergo further development before it can be used with confidence. Both models could be upgraded to include other agronomic factors such as the methods of cultivation, sowing and $\mathrm{P}$ application.

\section{ACKNOWLEDGEMENTS}

Funding from Ballance Agri-Nutrients. The authors thank all Plant \& Food Research employees, past and present, who were involved in all the trials from 2002 to 2010, particularly Shane Marley, Nathan Arnold, Andrea Pearson, Mike George, Richard Sim, John de Ruiter and Derek Wilson.
Table 3 The root mean square of the deviation (RMSD) and adjusted coefficient of determination $\left(R^{2}\right)$ for turnip crops grown at different sites (Experiment D; Figure 3)

\begin{tabular}{lll}
\hline Site & RMSD (t/ha) & $\mathrm{R}^{2}$ \\
\hline Pirongia cultivated & $1.72(15.8)^{\mathrm{a}}$ & 0.95 \\
Pirongia direct drilled & $1.06(13.1)$ & 0.99 \\
Henderson cultivated & $0.77(8.3)$ & 0.93 \\
Henderson direct drilled & $1.43(14.0)$ & 0.41 \\
Henderson cultivated, seed & $0.72(7.8)$ & 0.96 \\
broadcast & & \\
Lincoln luxury N & $0.26(2.6)$ & - $^{\mathrm{b}}$ \\
\hline aNumbers in parenthesis are the percentage of RMSD. \\
bStraight line (model predicted the same yield across treat- \\
ments).
\end{tabular}

\section{REFERENCES}

Adams, C.M.; Scott, W.R.; Wilson, D.R.; Purves, L. 2005. Dry matter accumulation and phenological development of four brassica cultivars sown in Canterbury. Agronomy New Zealand 35: 1-18.

Chakwizira, E.; De Ruiter, J.M.; Brown, H.E.; Wheeler, D.M.; Shepherd, M. 2011. Parameter development for adding fodder crops to OVERSEER ${ }^{\circledR}$ nutrients budgets. Kale and turnips. In: Adding to the knowledge base for the nutrient manager. Eds. Currie, L. D.; Christensen, C. L. http://flrc.massey. ac.nz/publications.html. Occasional Report No. 24. Fertilizer and Lime Research Centre, Massey University, Palmerston North, New Zealand. 12 pp.

Chakwizira, E.; Moot, D.J.; Scott, W.R.; Fletcher, A.L. 2009. Effect of rate and method of phosphorus application on the growth and development of 'Pasja' crops. Proceedings of the New Zealand Grassland Association 71: 101-106.

Chapman, H.M.; Bannister, P. 1994. Vegetative production and performance of Calluna vulgaris in New Zealand, with particular reference to Tongariro National Park. New Zealand Journal of Ecology 18: 109-121.

Charlton, D.; Stewart, A. 2006. Forage brassicas. Pasture and forage plants for New Zealand. Grassland Research and Practice Series 8, Third Edition. New Zealand Grassland Association. 128 pp. Cornforth, S.; Stephen, R.C.; Barry, T.N.; Baird, G.A. 1978. Mineral content of swedes, turnips, and kale. New Zealand Journal of Experimental Agriculture 6: 151-156.

Cichota, R.; Brown, H.E.; Snow, V.O.; Wheeler, D.M.; Hedderley, D.; Zyskowski, R.F.; Thomas, S. 2010. A nitrogen balance model for environmental accountability in cropping systems. New Zealand Journal of Crop and Horticultural Science 38: 189207. 
de Ruiter, J.M.; Wilson, D.R.; Maley, S.; Fletcher, A.L.; Fraser, T.J.; Scott, W.R.; Dumbleton, A.J.; Berryman, S.; Nichol, W. 2009. Fertiliser guidelines. pp. 2331. In: Management practices for forage brassicas. New Zealand Institute for Plant and Food Research. ISBN 978-0-9864540-2-8. Christchurch. http://www. dairynz.co.nz/file/fileid/33375.

Fletcher, A.L.; Chakwizira, E. 2011. Developing a critical nitrogen dilution curve for forage brassicas to manage N and crop quality. Grass and Forage Science In Press.

Jacobs, J.L.; Ward, G.N.; McDowell, A.M.; Kearney, G.A. 2001. A survey on the effect of establishment techniques, crop management, moisture availability and soil type on turnip dry matter yields and nutritive characteristics in western Victoria. Australian Journal of Experimental Agriculture 41: 743-751.

Jamieson, P.D.; Francis, G.S.; Wilson, D.R.; Martin, R.J. 1995. Effects of water deficits on evapotranspiration from barley. Agricultural and Forestry Meteorology 76: 41-58.

Jamieson, P.D.; Zyskowski, R.F.; Sinton, S.M.; Brown, H.E.; Buttler, R.C. 2006. The Potato Calculator: A tool for scheduling nitrogen fertiliser application. Agronomy New Zealand 35: 49-53.

Kobayashi, K.; Salam, M.U. 2000. Comparing simulated and measured values using mean squared deviation and its components. Agronomy Journal 92: 345-352

McLaren, R.G.; Cameron, K.C. 1996. Soil science: sustainable production and environmental protection. 2nd ed. Oxford University Press, Auckland. 218 pp.

Martin, R.J.; Wilson, D.R.; Gillespie, R.; Maley, S.; Riddle, M. 2006. Effect of water deficit on yield of Pasja forage brassica. In: Proceedings of the 13th Australian Agronomy Conference. Perth, Western Australia.
Parfitt, R.L.; Clayden, B. 1991. Andisols - the development of a new order in soil taxonomy. Geoderma 49: 181-198.

Pearson, A.J.; Thomson, N.A. 1996. Effect of nitrogen and phosphate fertilizer on the yield and nitrogen content of Barkant turnips sown as a summer supplementary feed for dairy cows in Taranaki. Agronomy New Zealand 26: 37-43.

Reid, J.B. 2002. Yield response to nutrient supply across a wide range of conditions 1. Model derivation. Field Crops Research 77: 161-171.

Reid, J.B.; Stone, P.J.; Pearson, A.J.; Cloughley, C.; Wilson, D.R. 1999. The maize calculator - a simple system for predicting fertiliser nitrogen requirements of maize. Agronomy New Zealand 29: 73-74.

Reid, J.B.; Stone, P.J.; Pearson, A.J.; Wilson, D.R. 2002. Yield response to nutrient supply across a wide range of conditions 2. Analysis of maize yields. Field Crops Research 77: 173-189.

Williams, P.H.; Tregurtha, R.J.; Francis, G.S. 2003. Fate of urea applied to winter spinach in New Zealand. Nutrient Cycling in Agroecosystems 67: 245-254.

Willmott, C.J. 1982. Some comments on the evaluation of model performance. Bulletin of the American Meteorological Society 63: 1309-1313.

Wilson, D.R.; Reid, J.B.; Zyskowski, R.F.; Maley, S.; Pearson, A.J.; Armstrong, S.D.; Catto, W.D.; Stafford, A.D. 2006. Forecasting fertiliser requirements of forage brassica crops. Proceedings of the New Zealand Grassland Association 68: 205-210. 